\title{
Designing robust and revisable policies for gender equality: lessons from the Australian construction industry
}

\author{
Natalie Galea, Abigail Powell, Martin Loosemore \& Louise Chappell
}

The construction industry remains the most male dominated sector in Australia. Several decades of formal gender equality initiatives by government and business have failed to bring about any meaningful change to the hierarchical and numerical representation of women in the sector. Drawing on new institutionalism, particularly the concepts of 'robustness' and 'revisability', the nature and intent of formal policies and programs that impact on gender equality are analysed in two large Australian multinational construction firms. Through in-depth interviews with senior management and a document analysis of formal policies, it is concluded that gender equality initiatives and broader policies are primarily focused on increasing the numbers of women in construction rather than addressing gender practices and outcomes. These policies lack many of the qualities of robustness and revisability, which impacts on their capacity to genuinely challenge the gendered norms, practices and narratives of the sector.

Keywords: Equality; gender; new institutionalism; policy; rules.

\section{Introduction}

The lack of gender equality in the construction sector is a persistent problem recognized in Australia and elsewhere (Dainty et al., 2000, 2007; Powell and Sang, 2013). This lack of equality is a concern because it has been shown to exacerbate skills shortages, reduce productivity and constrain innovation (Toohey et al., 2009). Despite many reforms to increase the numerical and hierarchical representation of women in construction in Australia, it remains the most male dominated sector in the country (Equal Opportunity for Women in the Workplace Agency, 2012). Indeed, recent figures show the situation is deteriorating. Between 2006 and 2012 women's participation fell from $17 \%$ of the Australian construction workforce (Australian Bureau of Statistics, 2006) to 11.6\% (Equal Opportunity for Women in the Workplace Agency, 2012). Women in construction fare poorly not only among technicians, trades, labourers and machinery operators (3\%), but also in professional and management roles (14\%) (Australian Bureau of Statistics, 2012). Gender segregation exists both horizontally and vertically in many countries, including Australia, with men numerically and hierarchically overrepresented (Sang and Powell, 2012). Men dominate senior 'technical', 'feeearning' careers, while women congregate in junior, support roles and non-fee-earning professions such as human resources and marketing. Early enthusiasm by women about construction professions and their future careers in the sector decreases with increased exposure to the workplace as they experience relative disadvantage and inequality in pay, development and promotional opportunities compared to their male counterparts (Dainty et al., 2000). It therefore comes as little surprise that in Australia, women are leaving the construction professions almost 39\% faster than their male colleagues (Association of Professional Engineers, Scientists and Managers, 2010).

The Australian government has introduced a range of laws and regulations around gender discrimination and harassment to underpin the legal case for gender equality and diversity across all 
economic sectors. For example, in 2012 legislative adjustments were made by the Australian Federal Government requiring all companies with more than 100 employees to report on the gender composition of their workforce (Workplace Gender Equality Agency, 2012). There are also 'soft' instruments in place to encourage change towards gender equality including the 2010 Australian Stock Exchange (ASX) Corporate Governance Guidelines which provide for non-mandatory requirements for disclosure and reporting of equality policies and gender targets for all publicly listed corporations. Despite these various initiatives, barriers to gender equality remain in many construction firms, including covert and overt discrimination, a lack of networking opportunities, expectations of total availability and challenges balancing work/family commitments (Sang and Powell, 2012). There is also often an expectation of working unsociable hours, often in remote locations, and the continued dominance of a culture which emphasizes long hours and 'presenteeism' is problematic for many, particularly women who continue to carry the burden of caring responsibilities (Watts, 2007). Further problems include poorly designed company policies and procedures, which fail to consider potentially gendered consequences. These include informal recruitment and promotion and progression practices undertaken by operational line managers such as favouring the recruitment of applicants with existing internal company contacts and stereotyping expectations of women candidates' future personal priorities (Dainty et al., 2000).

The intractability of gender inequalities in construction calls for a fresh approach. As Dainty et al. (2007) point out analysis of this problem is recognized as being theoretically weak. To address this weakness, 'new institutionalist' (NI) theory is used to analyse the nature and intent of 'formal' policies and programs that may directly or indirectly impact on the attraction, retention and progression of women professionals in the construction industry.

This article proceeds in three parts. Part one discusses the importance of new institutionalism for analysing gender outcomes, including in the construction sector, and outlines the methods used in this study. Part two discusses the design of policies that may directly or indirectly impact on gender equality, drawing attention to where elements of robustness and revisability have been present or absent. Part three advances the core argument of the article that the failure of formal policies to address women's disadvantaged position in the Australian construction sector and is in part due to poor policy design, especially the lack of connection between policies and company values and an absence of flexible and variable design features.

\section{Part one: Assessing gender equality through a new institutionalist approach}

New institutionalism offers a valuable new approach for examining gender equality in the construction sector. The basic premise of new institutionalism is that institutions 'matter' because they rule in certain practices and rule out others (March and Olsen, 1984, p. 747). Although there are important epistemological differences in approaches that fall under the new institutionalist umbrella (ranging from rational choice, historical, sociological, discursive and now feminist institutionalism), the most recent work in the field pays attention to the underlying points of convergence and the multi-theoretic perspective (Lowndes, 2002, p. 108; see Mackay et al., 2010). Lowndes and Roberts' (2013) work is central to this effort, suggesting that we have now entered a 'third wave' of new institutionalism scholarship where there is agreement across all approaches that institutions are forms of social organization that may be both 'formal' (e.g. codes of conduct, contracts, procedures, policies, laws) and 'informal' (e.g. norms, practices and narratives). Individuals within organizations through processes of negotiation and conflict devise these rules, and these rules govern the way people interact and behave. While institutions are devised by actors they also structure actors social interaction, as well as organizations and government by constraining and enabling their behaviour (Helmke and Levitsky, 2004) and shaping opportunities for change 
(Mahoney and Thelen, 2010). Institutions do this by outlining and rewarding acceptable behaviours and imposing sanctions for non-compliance (March and Olsen, 1984; Lowndes, 1996). Across all strands of new institutionalism, institutions are defined by the fact that they are resilient over time and produce stable and recurring patterns of behaviour, which are then reinforced and amended by people as they go about their lives and work (Dimaggio and Powell, 1983, 1991; Lowndes and Roberts, 2013).

Formal institutional rules are distinguished by the fact that they are consciously designed and clearly specified (Lowndes and Wilson, 2003), and disseminated and enforced through official channels: formal policy documents, legislation, courts, etc. (Helmke and Levitsky, 2004). By contrast, informal institutional rules are often 'hidden from view', tacit, undocumented and communicated and enforced through an organization's informal power structures and culture (Lauth, 2000; Helmke and Levitsky, 2004). Informal institutional rules are important, performing a variety of positive and negative functions in society and organizations. On the positive side, informal rules may substitute for formal rules that do not work (such as in a crisis) (Raymond et al., 2013). However, on the negative side, informal rules can be used to undermine formal rules when employed by actors who wish to maintain the status quo against new rules (Helmke and Levitsky, 2004).

The design of institutions is not a straightforward process and is normally the result of multiple designers who come to the task with different perspectives and objectives about their origin, nature and intent (Lowndes and Roberts, 2013). Furthermore, policy designers often face constraints and challenges in the creation and implementation of new policies and procedures as organizations have the capacity to 'absorb or deflect new initiatives' (Newman, 2001, p. 28). Further, poor design, weak implementation or a lack of active maintenance and revision of policies may lead to them being ineffectual and unenforceable in practice (Meyer and Rowan, 1991).

$\mathrm{NI}$ scholarship has been critiqued on a number of levels. Peter John (2013) suggests greater convergence in the new institutionalist literature has meant that institutions have become a 'catch all' category, now encompassing ideas and discourses, which has meant institutions as a variable have lost some of their explanatory edge. John, along with others, has also criticized institutionalism as being much better at identifying institutional stasis than at identifying change. A third critique has rested on the lack of practical application of the new institutionalist approach, especially about the constraints and challenges associated with 'good' institutional design: that is, one where implementation mirrors as closely as possible the objectives and intentions of the designers. Finally, feminist scholars have also challenged existing approaches for their gender blindness (Mackay et al., 2010). Within the feminist institutionalist paradigm it is argued that the rules of the game (both formal and informal rules) are gendered. These rules establish, construct and maintain gendered power relations and dynamics between men and women and shape the outcomes and opportunities for gender change in institutional settings (Krook and Mackay, 2011).

This article engages directly with these last two points of critique. Drawing on the work of UK institutionalist scholar Vivien Lowndes in association with Wilson (Lowndes and Wilson, 2003) and Roberts (Lowndes and Roberts, 2013), this article seeks to give greater clarity to measures of 'good' design, specifically to features of institutional 'robustness' and 'revisability'. In addition, emergent feminist institutionalist scholarship provides guidance on understanding, how these design features of the formal rules might impact on gender equality outcomes. Specifically we define formal rules as documented policies, guidelines, programs, initiatives or strategies. In line with Helmke and Levitsky's definition (2004), the formality of these rules is delineated by the fact that they are written down and have some stated mechanism for enforcement via a third party, either through a (potential) reward or sanction. 
Following Lowndes and Roberts, robustness is used to refer to the maintenance of policy strength and resistance to change over time. It is operationalized through: clarity of values underpinning and being tied to ongoing policy design; and the nature and effectiveness of policy enforcement, usually through third party sanctioning or endorsement. Put simply, enforcement exists when actors know they are breaking the rules and when someone cares whether rules are followed and adhered to (Lowndes and Roberts, 2013). Values and policy enforcement can be explicitly stated in formal rules or operate informally through practices, norms and narratives. These may sit in alignment or in tension with one another. This paper seeks to investigate whether formal values and enforcement processes are inscribed into policy and programs. Subsequent stages of this research project will examine the operation of informal rules on gender diversity outcomes, including examining how enforcement of these informal rules occurs. For our purposes here it is important to note that a good fit between values and enforcement matter to shaping design objectives; an alignment between these two help policies to 'stick' and shape organizational behaviour. (Lowndes and Roberts, 2013). Revisability is defined as the capacity for policy amendment or alteration, which is required when a policy fails to achieve its stated objective. It is operationalized through: (1) flexibility and adaptation of policy design through policy learning over time; and (2) variability in policy design and the extent to which there is tolerance of different design variants in different locations (Lowndes and Wilson, 2003). Policy learning and the subsequent adjustment of policies serves to minimise gaps in the configuration of different policy tools which mitigates against unexpected effects. While variability in policy design, provides an avenue for innovation and learning (Lowndes and Roberts, 2013). This is relevant to construction where policies often originate in head office and are implemented on site.

\section{Methods}

A feminist institutional lens is used to explore the design of the construction sector's formal institutions in the area of gender equality, analyse their degree of robustness and revisability, and assess how the absence or presence of these features in the design of the rules impacts on gender equality outcomes. Using a new institutionalist framework, our premise is that a lack of robustness and revisability in policy and program design may be a key factor influencing the lack of progress in improving women's representation and gender equality in the construction sector. Revisability and robustness are the two concepts through which we analyse our data. The data is drawn from two case studies of large tier-one multinational construction companies based in Australia. The case study approach is frequently used in both organizational and policy analysis studies (Lowndes and Wilson, 2003) to provide a valid and nuanced, though not necessarily generalizable, view of reality (Flyvbjerg, 2006). It also provides an opportunity to test theories in new contexts (Patton and Appelbaum, 2003), in this case, NI theory in a construction context.

Both case studies are major contractors which operate in the Australian commercial, residential, engineering and infrastructure markets. The structure of both companies is typical and representative of large global construction companies. Company $A$ is led and managed by a CEO and executive management team, which is composed of regional managing directors, legal counsel and strategy, safety, human resource and operations directors. Company B is led and managed by a board and CEO and an executive management team, which is composed of regional and discipline specific executives, legal counsel and corporate affairs personnel.

Our study adopted a qualitative approach and our methods involved document analysis and semistructured interviews. The document analysis focused on formal policies relating to the attraction, recruitment, retention and progression of both women and men. Documents supplied by each case study company included policies, strategies, internal communications, existing staff engagement 
surveys and internal research relating to flexibility, equality, learning and development, code of conduct, harassment and bullying, parental and care leave, performance and remuneration including pay equity analysis. We examined policies other than those directly aimed at addressing gender equality (such as the pay equity analysis), since feminist institutionalism suggests all rules can have gendered outcomes (Chappell and Waylen, 2013). Current versions of policy documents were analysed, although superseded versions were requested to provide historical context. In total, Company A provided 48 documents and Company B provided 21 documents for analysis (see Table 1 for a summary). In addition, Company A provided internal research undertaken via staff surveys and focus groups. The document analysis set out to scope the breadth of policy instruments used by the companies, their focus and specificity. Document analysis identified formal policy and programs and whether policy documentation responded to, or was understood by key actors to respond to, Lowndes and Wilson's (2003) robustness and revisability framework, with a focus on documented values, formal enforcement mechanisms, company learning and flexibility of application.

In addition, 20 semi-structured interviews (10 in each company) were conducted with purposefully sampled business leaders who included: policy designers, HR managers, diversity leaders, senior executives, the CEO and chief operating officer (COO). The interview questions were devised in light of the document analysis, and were used to better understand the context in which the formal policies were developed, enforced and monitored and adjusted. The semi-structured nature of the interviews also enabled interviewees to raise other salient issues. These include interviewee's interpretation of gender diversity, their understanding of policies and programs and how gender diversity is positioned within the business. Table 2 provides a summary of the characteristics of interviewees by gender, position and whether the interviewee undertakes an operational or a functional role. To protect the anonymity of interviewees, specific roles and job titles cannot be identified. Identifying operational and functional roles within construction organizations is important as those in operational roles (e.g. construction management, project management, contracts administration, commercial management) represent the dominant group, and are primarily construction or engineering professionals who are charged with delivering the core business function. By contrast, those in functional roles (e.g. human resources, marketing, legal, accounting, administration, IT) represent multifaceted professions who support the general operation of the business and who are usually responsible for authoring HR policies. Having said this, those in operational roles are responsible for implementing HR policies, particularly in relation to recruitment and progression (Dainty et al., 2000).

The interviews aimed to build a picture of the nature and intent of policies and programs impacting on gender diversity and develop an understanding of how these policies were sourced, designed, disseminated, measured and enforced. As noted above, interviews were used to provide context to the document analysis: as such they included questions about the company's approach to gender equality; the evolution of gender-related policies; the types of initiatives and policies in place; policy drivers; how policies were monitored and revised; and, successes and challenges in implementation. Interviews typically lasted 60-90 minutes and, with permission, were recorded. Subsequently interviews were transcribed verbatim and anonymized to protect interviewee identities. As with the document analysis, analysis of the interview data was informed by Lowndes and Wilson's (2003) theoretical framework of robustness and revisability, while remaining sensitive to other themes emerging from the data, particularly the document analysis, as well as tensions and contradictions.

The findings presented in the following section focus on significant points raised in the narrative of the interviews rather than on counts of how many interviewees said specific things or how often something was cited in policy documents. This is appropriate for our qualitative approach as we wanted to build a picture of respondents' experiences of working with formal gender equality 
policies and other policies that may produce gendered outcomes. Further, by presenting narratives we are able to retain the full richness of insight from the interviewees. Meisel and Karlawish (2011) argue that the power of narrative is in translating respondent accounts into data that people can comprehend. Clearly, it is not possible to recount everything participants said; instead we present the main themes emerging from the data, with interview quotes selected to illustrate these themes. These interviews provide the foundation for Stage 1 of this research project, which is focused on understanding the operation of the formal rules. Stage 2 of the research project is designed to further analyze revisability and robustness by focusing on the informal rules at work, a task that will be undertaken via a 'rapid ethnographic' approach (Millen, 2000; Isaacs, 2013) which will include shadowing and close observations of behavior within these two companies.

\section{Part two: Features of policy design impacting on gender equality in the Australian construction sector}

An analysis of the policies introduced by both companies under review in the last three to five years demonstrates that they have introduced a variety of formal gender equality policies and initiatives, as well as broader policies may indirectly impact on gender equality issues. Some of these were sourced and developed internally; others were developed via external consultants. Policies and programs in both companies shared a focus on parental and care leave, affirmative action towards women in graduate recruitment, gender bias training for recruiters and management, women support groups, flexible work arrangements, equality policies and gender diversity committees. In both companies policies such as the code of conduct and parental and care leave appeared to respond directly to, and often exceeded, their legislative responsibilities. An analysis of these policies and the interview data suggest two important points. First, most of the gender equality strategies and initiatives had a focus on women; second, from a formal perspective many were missing the core features of robustness and revisability. As discussed below, policies and programs can be enforced through informal mechanisms for example, and will be the subject of future research stages of this research.

\section{Understanding gender equality: the woman problem}

Although research demonstrates that gender equality policies can improve the attraction and retention of talent in construction (Daley et al., 2012), interviewees in both case studies demonstrated a spectrum of understanding and awareness around gender-related issues. Most interviewees associated the issue of gender equality with women, rather than an issue concerning both men and women. Most commonly, the problem of gender equality was perceived as a problem of recruitment and retention that would be resolved by building a critical mass of women in the industry.

I think there's a pretty strong push in the industry and strong recognition that we've got to get more women in. (RESP \#4, Operational role, Male, Company A)

Interviewees for the most part offered women-centred explanations for women's underrepresentation in construction; a common theme was the problem of the lack of women in the recruitment 'pipeline', stemming from a lack of engineering and construction management graduates. Interviewees did not justify men's overrepresentation, nor associate gender with men; in other words there was no inversion of the problem to one of 'male advantage' (Lewis and Humbert, 2010; Murray, 2014). Few male interviewees were reflective of their own or other men's 
experiences in relation to gendered work practices (such as a culture of long hours and 'presenteeism') or societal influences and gender bias. This was interesting, as research has repeatedly acknowledged masculine culture in the construction industry in holding back gender equality (Barnard et al., 2010).

The research identified some disparity between men's and women's perceptions of the barriers and causes of gender inequality. Male respondents identified the key barriers to gender equality as the nature and inflexibility of the industry, the lack of women graduating from construction related courses and personal preferences or choices made by women. As one male interviewee summarized it:

\title{
We are still struggling with gender diversity because there are just not enough women in the market or coming through at a graduate level. (RESP \#2, Operational role, Man, Company A)
}

Conversely, women identified the dominant male culture, assumptions and stereotypes made about women and the lack of flexibility in the industry:

\author{
When we did ... some dedicated workshops in each region with a group of males \\ and females ... We got ... some fairly eye opening feedback about how differently \\ things can be perceived ... That was fed back to the executives and that - there's \\ some things that really stand out for them. Some comments about girls playing \\ with dolls and boys with Lego. Just some archaic type thinking that you're still \\ unearthing from that whole piece. So then recommendations came through from \\ that about the need to focus on career development and one up career \\ conversations for females. (RESP \#9, Functional role, Woman, Company A)
}

The view that gender (in)equality in construction was a 'woman problem' may help explain why the majority of policies were directed towards women and not men. However, a closer look at the existing formal policies and interview data also revealed that these policies were also lacking in other ways, particularly in relation to their robust and revisability features.

\section{Robustness and revisability in the design of gender policy}

The proposition of this research, drawing on the work of new institutionalist theorists Lowndes and Wilson (2003) is that the more robust and revisable the design of the formal rules, the more likely rules are to become entrenched and 'stick' over time. Applying this framework to the policies and initiatives of the two organizations in this study, a mixed picture emerges. Table 3 applies a robustness and revisability framework to the suite of policies analysed, which were both generic and gender equality specific, and are grouped according to the policy theme.

\section{Robustness: values}

Policy robustness is operationalized in the first instance through a clear tie to organizational values (Lowndes and Wilson, 2003). In our case study organizations, there appears to be a mismatch 
between policies and values. In terms of policy robustness, our interviews suggest that business imperatives, external regulations, talent attraction and leadership, rather than company values have underpinned gender equality policy awareness and motivation in these firms. This is not to say that these additional issues are unimportant, but that they may be less helpful than company values in embedding policies and programs. Interestingly, the business case for gender equality and talent acquisition and retention is clearly stated in the gender diversity policies of both companies, but values were not. Subsequent stages of the research will investigate whether the informal enactment of policies was tied to company values, and the effect this has had on gender diversity policy outcomes.

In Company A, the design and development of gender equality policies in the organization within the last four to five years were identified as being triggered by management's concern about a talent and skills shortage in the sector due to the recent construction and mining boom period in Australia:

\begin{abstract}
We've had some economic conditions that were interesting, first we had the GFC, so you know you could pick and choose what resources you wanted but not long after that...our business was heavily impacted by a number of factors including the mining boom ... so it almost like kicked you up the butt that you had to think shit load more about your people. (RESP \#3, Functional role, Woman, Company A)
\end{abstract}

In Company B, interviewees indicated that gender equality was a long-standing company focus, which gained greater prominence in recent years. As one business leader stated:

\begin{abstract}
I've always felt that we recognized diversity, even though we may not have used the word back in the 90s or even in the late 80s, I still feel for [company] there was a recognition and a respect of you know that this place is better if it's made up of different people. Not saying it was successful in doing that, but I think it was always on the radar. I think over the last couple of years it's just become a little bit more clearly stated, so here is a principle - one of three key principles in this organization is about diversity in all forms. (RESP \#13, Operational role, Man, Company B)
\end{abstract}

However, gender equality was not a documented company value and interviewees did not specify other company values as a driver behind gender equality policies.

In Company A, a shift towards greater gender equality concerns was particularly noticeable to interviewees three years ago, with the appointment of a new CEO from within the company, the introduction of an executive management team inclusive of a small number of women and a change in HR leadership:

\footnotetext{
[The HR Director] and the other women on the executive management team ... they are the main agitators. (RESP \#2, Operational role, Man, Company A)
} 


\author{
Who really makes the difference - it will be the CEO and then the regional \\ managing directors because they are the drivers - I suppose I have a very old \\ fashioned, simplistic view ... what interests my boss absolutely fascinates me. So \\ my sense is unless things are being driven by those business leaders then it's not \\ going to be in play. (RESP \#7, Functional role, Man, Company A)
}

Yet it was noted by RESP \#10 (woman in functional role in Company A), that there were 'variations of readiness' for policy development in this area within the executive management team. She stated, 'I think they're all ready, but I think some are here and doing it and others are trying to still get their head around what it is that they're doing, and why.' This points to the importance of investigating informal rules in later stages of the research, which may interact positively or negatively with formal rules.

In Company B, three respondents thought the leadership, of women in particular, was important. Interviewees drew attention to the role of a former female chairperson of the company and other high profile women in helping gender equality issues gain momentum within the company.

\title{
I think it's evolved over time. I certainly think it's got more momentum in the last five or so years and some of that's through the high profile women that we have had in the organization both now and in the past. (RESP \#15, Operational role, Man, Company $B$ )
}

Interviewees in both companies also identified the Australian Stock Exchange (ASX) reporting rules as influencing policy developments in this area. One Company B interviewee suggested the ASX rules helped move gender issues from a human resources frame to 'being at the forefront of the attention of the business leaders' (RESP \#11, Functional role, Woman, Company B). This response was mirrored by an interviewee in Company A (RESP \#6, Operational role, Man, Company A) who added that high profile legislative changes to gender reporting through the ASX and paid parental leave in Australia also brought about a heightened market awareness of gender equality.

While external regulation, leadership and business imperatives were credited by interviewees for driving efforts towards greater gender equality, company values were not. This was reflected in many of the policy documents where company values were rarely stated or credited with underpinning policy establishment and enforcement.

An analysis of Company A's values demonstrated an emphasis on nurture, teamwork, honesty and excellence; values that according to one interviewee are set within a 'can do' culture (RESP \#6, Operational role, Man, Company A). Interviewees from Company A perceived that company values sat alongside the stated 'DNA' or unique company identity which promotes competition, humility, passion and tenacity, larrikinism, 1 ambition, work hard: play hard(er), family feel - friends, care of people and love to start: love to finish. However, there appeared to be tensions between the company's DNA and its documented values. This suggests there is sometimes conflict between formal and informal values, or the informal practices of how the formal rules are enacted, which will be further investigated in Stage 2. For example, competition, larrikinism and the 'work hard: play hard(er)' approach, imply that work and play are the only dimensions of life, with little recognition of care and domestic responsibilities (Massey, 1994). As such they reflect well-identified hegemonic 
masculine values that are revered in construction (lacuone, 2005) and which sit in contrast to the values of nurture and teamwork articulated in formal policy documents.

In Company A, with the exception of the flexibility policy, company values were absent from many of the policy documents, including those relating to diversity, bias training, parental leave, talent and succession planning and gender pay analysis. Values were not clearly specified in documents that describe company leadership traits, the company's DNA, graduate and employee learning and development, the employee survey and the remuneration review. By contrast, Company A's values were clearly stated in the company's leadership framework and leadership programme, employee induction and the flexibility policy.

Company B's stated values include honesty, teamwork, consideration, greatness, creativity and reliability. Interviewees identified multiple ways that Company B conveyed company values, including via key principles, mission statements, vision and company value statements. However, there appeared to be a confusion of these values across the multiple mediums through which company values are expressed and disseminated. This was articulated from an employee perspective when one interviewee noted:

[The Company] has muddled the waters a bit because we have this vision, we have a mission, we have values and we have key principles. So employees are starting to get confused about which things are important. (RESP \#18, Operational role, Woman, Company B)

In Company B's policy documents, values were clearly stated in the code of conduct and the flexible work policy; however only 'consideration' and 'teamwork' were noted in the diversity and inclusion policy and the harassment and bullying policy. Company values were not clearly specified in policy documents associated with its leadership framework and performance reviews. The flexibility initiative was designed to enable employees to discuss their individual flexibility needs with their manager. Some respondents expressed excitement about the flexibility initiative. However it was acknowledged that there had been poor take-up since it was rolled out. One respondent reasoned that employees perceived it as a 'woman-centric policy'. He also noted that workplace expectations, particularly when projects were near completion or behind schedule, had not yet shifted:

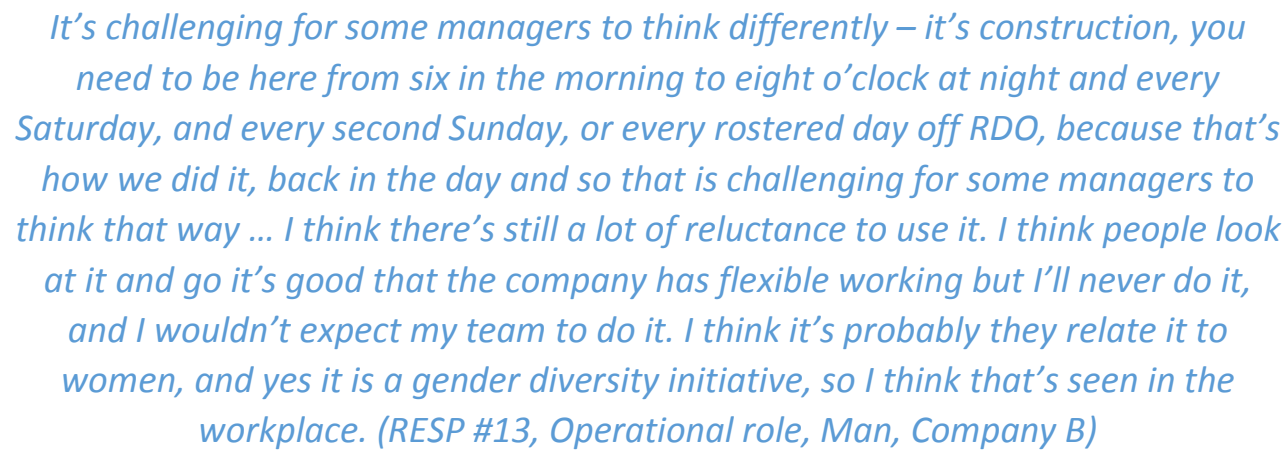

Again, this highlights the need to investigate how informal rules may interact with the formal. Specifically whether it is informal norms, practices and narratives that are acting as a barrier to the 
take-up or implementation of formal policies such as the flexibility initiative. Conversely, interviews suggested that the introduction of formal flexibility initiatives shifted employee expectations and norms associated with flexible work patterns. There was also some cynicism around the motivations for the flexibility policy. As one respondent perceived it, the policy had little to do with accommodating the needs of women but was established to provide support to divorced men with caring responsibilities:

\begin{abstract}
My belief is the reason why work life balance is coming in, and flexible work, has nothing to do with women. It has to do with divorced dads. So the only reason it's back on the agenda is because you have all these divorced dads who have to pick their kids up once a week at a certain time. So fundamentally the correlation between women and rights really only happened because all of a sudden men need to do the same stuff women had to do for years. (RESP \#18, Operational role, Woman, Company B)
\end{abstract}

Interviewees in Company B also indicated that although diversity was a core principle, it was not a top priority, unlike safety issues for example. One interviewee spoke about how safety initiatives had gained momentum in the company after reaching a crisis point, but thought this critical 'crisis' driver was missing in relation to equality. Another interviewee also spoke about equality being a secondary priority:

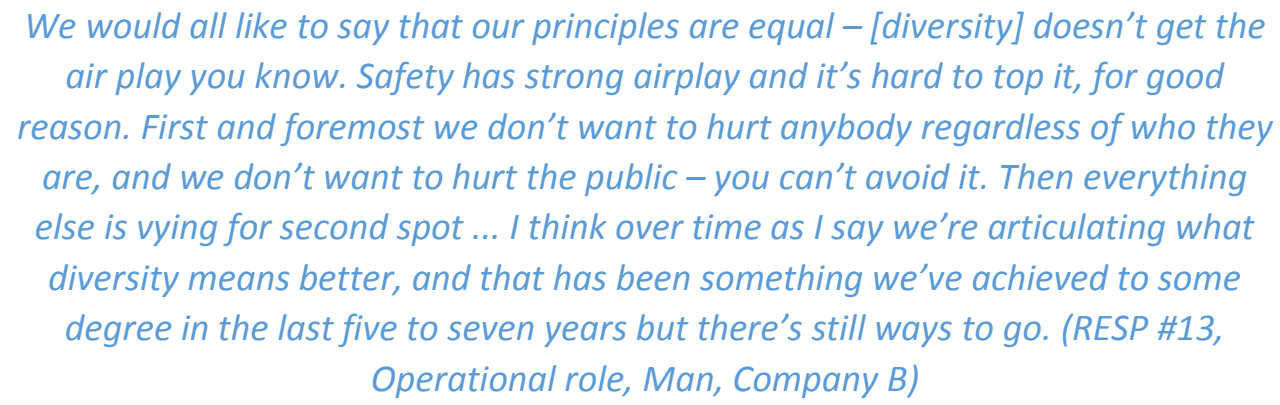
air play you know. Safety has strong airplay and it's hard to top it, for good reason. First and foremost we don't want to hurt anybody regardless of who they are, and we don't want to hurt the public - you can't avoid it. Then everything else is vying for second spot ... I think over time as I say we're articulating what diversity means better, and that has been something we've achieved to some degree in the last five to seven years but there's still ways to go. (RESP \#13, Operational role, Man, Company B)

It was also evident from the flexibility initiative in Company B that the values formally outlined in company statements were not necessarily the only values adhered to by employees. Other 'informal' values and practices, such as 'presenteeism' and an ethic of doing what was necessary to get the job done, were disrupting formal gender equality policy intentions. These 'traditional' implicit values, found in both firms, make it challenging to shift practices towards gender equality, especially where they are seen as legitimate in the eyes of the majority of employees and supported by normative practices (Lowndes and Roberts, 2013). Together, the perception that gender equality is a problem for women but not men, the lack of alignment between formal company values and gender equality policies, and the operation of these competing implicit values, help to undermine the purpose of the gender equality objectives of both companies' policies.

\section{Robustness: enforcement}

The second way in which robustness is operationalized, according to Lowndes and Wilson (2003) is through effective enforcement. In our case studies enforcement of policies was generally not clearly 
articulated in policy documents. However, we did not investigate more informal enforcement of formal rules at this stage. This was the case in Company A, with the exception of company induction presentations and the code of conduct and ethics, which stated harassment and discrimination breaches (including by those who condone this behaviour) would be investigated and may result in disciplinary action including dismissal. Similarly in Company B, only the code of conduct detailed how enforcement would be enacted, again in relation to harassment and discrimination. Company B's diversity strategy suggested positive sanctioning through reward and recognition would be undertaken, yet it did not provide specific details.

The lack of specification about formal internal enforcement mechanisms in the policy documents was reflected in the response of interviewees. Although most respondents indicated that their company took gender equality seriously, most were unable to recall specific policy details. This was a particularly marked response in Company B. In Company A, broadly speaking, interviewees did not discuss enforcement strategies with the exception of the pay equality, the flexibility pilot and internal recruitment practices. In the case of pay equality, despite some opposition to the policy at senior levels, the CEO was believed by many respondents to have enforced the policy through clear messaging and prompt action. This is an example of enforcement through narratives rather than through more formal enforcement mechanisms outlined in formal documents. Similarly, the CEO and executive leadership team have been considered critical to addressing resistance to the flexibility policy in Company A. This policy applies a 'whole of project approach' and involves all employees on one project being rostered on to work a five-day working week, while the project operates across a six-day week. Ongoing communication about the importance of this flexibility policy has been seen as important to its operation. A final area where enforcement was noted in Company A was in relation to bringing greater transparency to internal recruitment processes. Interviewees reported that previous employee transfers and promotions within the company had been hidden due to a lack of transparency between regions, resulting in talent loss. In addition to establishing an employee and recruitment tracking system that was reported to the national executive, interviews reveal that Company $A$ has also delegated to a senior executive the role of monitoring ongoing transparency. This demonstrates a commitment to using formal recruitment processes to advance gender diversity. This is significant as informal systems of recruitment and promotion have been identified elsewhere as a key barrier to women's entry to and progression in construction (Dainty et al., 2000).

Across both companies, interviewees' knowledge of how and to what extent other policies and initiatives were being adhered to appeared limited. Where interviewees in both companies did take note of the enforcement of gender equality initiatives, the enforcement mechanisms were described as informal, relying on manager discretion and were not believed to be a key performance indicator for senior executive officers. In many instances, formal enforcement strategies including direct controls, monitoring and sanctions appeared not to be in place. However, interviewees revealed that enforcement did occur, informally through conversations, usually between senior management and employees and via employee surveys. As one business leader in Company A reflected:

\footnotetext{
We haven't ... I mean so far I think it's - all the conversations, the anecdotal evidence and some of the stats is suggesting that it - that there has - has been some momentum. So I haven't had to have a carrot or a stick and, you know, I - I

think I'd have to address that one, you know, if - if we saw it trending that particular way. (RESP \#1, Operational role, Man, Company A)
} 
Similarly, in Company B gender equality initiatives were reportedly communicated to employees online and through 'roadshows' led by senior managers. This level of communication may be problematic because it cut out the operations managers who were the interface between project leaders and senior management and responsible for policy implementation. Policy dissemination and enforcement appear to rely on their discretion, interpretation and prioritization, again suggesting informal rather than formal enforcement. One business leader (RESP \#17, Operational role, Man) in Company $B$ recognized the lack of enforcement mechanisms as an issue, suggesting that building financial incentives or disincentives to promote the enforcement of gender equality policies should be introduced in their company to strengthen compliance.

\section{Revisability: flexibility}

Revisability is operationalized through policy flexibility and adaptability over time (Lowndes and Wilson, 2003). In this study, both construction firms had made efforts towards these aspects of revisability (undertaking extensive employee research and revision) leading to the introduction of new policies and initiatives (including flexible work practices and gender pay correction).

Company A undertook extensive and ongoing learning via employee engagement surveys, internal focus groups and quantitative analysis of employee remuneration. Some of Company A's initiatives originated from internal focus group research undertaken in 2013 which explored employees' perceptions of gender equality. A key outcome of the internal research in Company A was a focus on flexible work practices. Supported by results from the employee survey, which highlighted employee burnout and retention issues, a senior leadership group made flexibility a central concern and devised a pilot project, mentioned above, to address it. The group established the pilot study on a new construction project where they aimed to meet the programme with the project operational six days a week but with company employees working a rostered five-day week. Of course, the extent to which working five days per week can be considered flexible is debatable, but speaks to the entrenched nature of workplace practices in the construction industry. The pilot, identified in the policy documents as a 'flexibility "without guilt" plan', was considered by interviewees as critically important for the company and the industry as a whole.

\section{It's game changing for the industry if we can crack it in a way that I think is meaningful ... They're struggling but we'll get there. (RESP \#10, Functional role, Woman Company A)}

Yet, as mentioned earlier, in its introductory phase it was met with challenges associated with expectations placed on different site roles, particularly around responsibility and availability. Importantly, the pilot appeared to exclude the company's supply chain and subcontractors, who were still expected to be available to work a six-day week.

In Company B revision processes were not highlighted in policy documents. Interviewees indicated that there were opportunities for feedback via employee surveys, conducted biannually, and ongoing internal statistical analysis of women in the organization. In response to these initiatives a diversity committee and policies such as the flexibility initiative were established. On-the-job learning from programmes such as the flexibility initiative, where employees negotiate individual flexibility needs with their line manager have highlighted challenges, yet whether these were acted on was unclear. Whilst Company B's diversity strategy stated that it aimed to understand the state of play at policy commencement it did not stipulate how the strategy would be monitored. 
Despite the employee survey and statistical analysis, one business leader in Company B (RESP \#15, Operational role, Man) noted that if harassment or discrimination was occurring and went unreported, the company had no specific means outside what he described as 'the local telegraph' or via informal conversations to monitor its existence. Another business leader suggested that a lack of monitoring by Company B had resulted in talent loss:

\author{
I'm aware of ... another senior executive highlighted a lack of monitoring [by \\ Company B] resulting in talent loss she left. She would go home crying some \\ weekends just not being able to stand the behaviour and the prejudice - there \\ was a whole lot of issues. But it was invisible and to this day she's left and they \\ don't - so does that guy get accounted for? And that's happened as recently as a \\ couple of months ago so this is a seasoned female that's not a graduate. What \\ would happen if she speaks up? It wasn't harassment but it - it definitely was \\ blockers for her. (RESP \#20, Operational role, Woman, Company B)
}

It appears that whilst both companies perceived they were analysing policy performance, their analysis, like their policies, may be missing the mark. It appears that there were few formalized analysis processes and feedback loops; instead much is left to informal practices and to key individuals to decide how to respond to policy implementation gaps. While informal practices can have a positive impact, embedding formal rules, they are high risk as critical information necessary for redesigning policy can be easily lost or not properly integrated in policy revisions (Chappell and Waylen, 2013).

\title{
Revisability: variability
}

A second way in which revisability is operationalized is through policy design that responds to different locations and contexts and contributes to building innovative policy responses (Lowndes and Wilson, 2003). The interviews undertaken within both companies give some sense of where they sit. In Company A, interviewees suggested policies were disseminated using a topdown approach, rather than locally designed initiatives, again pointing to the strong role of narrative in this company:

\section{Same story and messages ... get cascaded down from the national exec to the state exec to the project managers on the site and the project manager on the site then cascades that stuff down through his - his project team. (RESP \#1, Operational role, Man, Company A)}

Policy design in Company A appeared to use a moderate level of variability with a range of initiatives which were focused on reducing barriers to gender equality and which could be applied to different contexts within the business. A business leader in Company A (RESP \#10, Operational role, Woman) noted the historic absence of employee performance appraisals, which resulted in reduced staff engagement and retention. The interviews and document analysis identified that management training in bias and performance appraisals, coupled with an employee and candidate recruitment framework and tracking system now operated nationally within Company A. Flexibility, whilst in the 
pilot stage had been designed so that it could be rolled out nationally within the company at the commencement of projects.

In Company B, some interviewees assessed policy variability as high, particularly for projects in remote locations. Interviewees acknowledged a higher degree of innovation among projects further away from head office.

$$
\begin{gathered}
\text { Actually in many cases we get better results remotely, people feel that they can } \\
\text { do more innovative things, a long way away from the head office, I don't know } \\
\text { why that is. People feel constrained close, but I'm - a number of our projects, our } \\
\text { sort of - they do some great things in the community. (RESP \#13, Operational } \\
\text { role, Man, Company B) }
\end{gathered}
$$

Policy documents analysed appeared generic in nature and adaptable to different locations, particularly project sites. In the case of flexibility, the policy document encouraged employees to negotiate their personal flexibility needs with their line manager. Despite this, only half of the interviewees in operational roles were aware of the flexibility initiative and able to cite comprehensively the gender equality policies offered by Company $B$. As a result it was unknown whether all gender equality policies were filtering through to regional project sites. A company restructure three years ago may explain why policies had yet to filter through the business; however, some interviewees also reasoned that information bombardment prevented them from being familiar with policies. This highlights a potential weakness of formal rules. Variability of policies for both companies appeared strong on paper; subsequent phases of this research project will explore how well on-site practices reflect these policy goals.

\section{Part three: Strengthening revisability and robustness in the Australian construction sector to advance gender equality outcomes}

The aim of this paper has been to use a feminist institutionalist approach, and the key concepts of robustness and revisability to analyse the intent and nature of 'formal' documented policies and programs that impact on gender equality in the construction industry. Robustness and revisability have proven to be useful tools for exploring the complexities of institutional design processes because they have helped to explain why some policies rather than others are successfully implemented and endure over time. Policies that are underpinned by company values and are effectively enforced are robust. Policies which have been developed, adapted from lessons learnt and which are flexible in their application are revisable. The combination of revisability and robustness is critical to embedding new rules and achieving change, in this case to gender practices.

This study has highlighted gaps in the robustness and revisability of formal policies and rules impacting on gender equality in two Australian construction companies. As the document analysis indicated, both companies have introduced a range of policy initiatives aimed at improving gender equality. However, there has been a mixed picture in how well these policies have been implemented. As interviews revealed, a lack of enforcement of the formal rules have left significant gaps, and informal rules have also interfered with successful implementation interfering with the intention of the formal rules, making it hard to have these policies 'stick' (Meyer and Rowan, 1991; Helmke and Levitsky, 2004). However, the data also suggests some changes have occurred, and where this has happened, informal rules and narratives have played an important role. In particular, internal narratives have played an important role in enforcing change. 
One significant problem has been the mismatch between core company values, often expressed informally, and formal gender equality policies. Inherent gendered norms and practices, such as long work hours, sit in conflict with attempts to support more flexible work hours that promote healthy lifestyles and support women and men with caring duties in the workplace. However, policies such as this also represent a first step in challenging informal norms and practices such as long work hours.

Policies and perceptions which emphasize gender equality as a women's issue, rather than one involving both genders, also undermine the robustness of policies, aimed at changing existing practices. Policies that are heavily focused on increasing the number of women in construction but not on shifting the gender practices or culture of construction may seem irrelevant to the majority of employees who are men and who arguably hold the power and key to changing the industry's culture. Furthermore, the policies appear to be low down the chain of organizational priorities, and traded off in favour of other formal rules, such as construction contracts and safety practices.

Another problem in relation to robustness has been a lack of consistency, coherence and coordination across all gender equality policies in both companies, resulting in different and confusing messages being disseminated. Formal or documented enforcement appeared to be weak in both companies. There were few documented sanctions or rewards for achieving gender equality objectives, which contributes to the (in)effectiveness of these policies (Meyer and Rowan, 1991). This is important because good policy design is not just about policy creation, but is an 'ongoing commitment to enforce rules, models of practices and rehearsed stories' (Lowndes and Roberts, 2013, p. 171). However, there did appear to be some informal enforcement, particularly through company narratives intended to support formal policies and programs.

Evidence from both case studies suggests that little attention has been paid to revisability. Although both companies have instituted processes to gather evidence about the position of women in their organizations, there appear to be no clear processes in place to redress problem areas or to revise policy to better target these areas. While it is still too early to evaluate, initial interviewee reactions further suggest neither company has fully explored flexibility options in its policy design, expecting a 'one size fits all' policy response to address a complex problem which operates in different ways at different scales of the organization. Policies aimed at addressing pay equity and transparent recruitment and promotion processes represent good HR practice. Yet assessment of their formal policies to date, suggest both have fallen short on deeper, innovative and transformative policy responses to the masculine workplace culture that has long been understood as a barrier to women's entry, retention and progression in the construction sector.

These findings demonstrate the value of new institutionalist theories in better understanding why gender equality initiatives may not 'stick' in the construction industry. They support the theory that both formal and informal institutions play a role in institutional design processes and in the implementation of the formal 'rules of the game'. These cases also support the point made by Goodin (1996) and Lowndes and Roberts (2013) about the 'messiness' of institutional design and implementation processes. The lack of a single designer and the inherent competing objectives underlying policies mean that the policies often fail to address the problems they were created to resolve. Where policy objectives require unsettling the gender status quo, the challenge is even greater. Gender biases are often embedded within formal and informal rules, making the task even more difficult because they are hard to see and to challenge (Chappell and Waylen, 2013).

This research does, of course, have limitations. Most notably the research is based on case studies, which cannot be generalized to the construction sector more broadly. This is not least because our case study companies are large, national contractors and the majority of the construction workforce 
is in fact employed in small-to-medium sized companies. Nevertheless, given that the larger companies are typically at the forefront of policy innovation, and supported by sizeable HR teams with responsibility for developing such policies, the study arguably provides a strong indication of what is happening in other large Australian construction companies. The study also provides a useful insight into how new institutionalist theory may be operationalized in the construction industry. It begins to explore how informal rules, practices and narratives support and challenge the formal rules. However, our focus on formal document analysis and interviews with business leaders rather than those at the coalface of policy implementation means we have not yet been able to fully explore the impact of the 'informal'. This will be the subject of subsequent research using ethnographic methods. As this research has done, it will aim to understand the complex dynamics acting for and against advancing gender equality in construction.

\section{Acknowledgements}

The authors would like to thank the participants that took part in this research. This research was supported under the Australian Research Council's Linkage funding scheme.

\section{Disclosure statement}

No potential conflict of interest was reported by the authors.

\section{Funding}

This work was supported by the Australian Research Council.

\section{Note}

1. Larrikinism is an Australian term which refers to a 'blokishness' that is good natured and mischievous yet irreverent to authority (Bellanta, 2012, p. xviii).

\section{References}

Association of Professional Engineers, Scientists and Managers (2010) Women in the Professions: The State of Play 2009-10, Association of Professional Engineers, Scientists and Managers, Melbourne.

Australian Bureau of Statistics (2006) Census of Population and Housing, Cat No 2068.0, Australian Bureau of Statistics, Canberra.

Australian Bureau of Statistics (2012) Labour Force Australia, Cat No 6202.0, Australian Bureau of Statistics, Canberra.

Barnard, S., Powell, A., Bagilhole, B. and Dainty, A. (2010) Researching uk women professionals in set: A critical review of current approaches. International Journal of Gender, Science and Technology, 2(3), 361-81.

Bellanta, M. (2012) Larrikins: A History, Univ. of Queensland Press, St. Lucia, Queensland.

Chappell, L. and Waylen, W. (2013) Gender and the hidden life of institutions. Public Administration, 91(3), 599-615.

Dainty, A., Bagilhole, B. and Neale, R. (2000) A grounded theory of women's career underachievement in large UK construction companies. Construction Management and Economics, 18(2), 239-50. 
Dainty, A., Green, S. and Bagilhole, B. (2007) People and Culture in Construction: A Reader, Taylor and Francis, London.

Daley, J., McGannon, C. and Ginnivan, L. (2012) Gamechangers: Economic Reform Priorities for Australia, Gratton Institute, Melbourne.

DiMaggio, P.J. and Powell, W.W. (1983) The iron cage revisited: Institutional isomorphism and collective rationality in organisational fields. American Sociological Review, 48(2), 147-60.

DiMaggio, P.J. and Powell, W.W. (1991) Introduction, in Powell, W.W. and Dimaggio, P.J. (eds.) The New Institutionalism in Organizational Analysis, University of Chicago Press, Chicago, IL, pp. 1-38.

Equal Opportunity for Women in the Workplace Agency (2012) Australian Census of Women in Leadership, Australian Goverment, Canberra.

Flyvbjerg, B. (2006) Five misunderstandings about case-study research. Qualitative Inquiry, 12(2), 219-45.

Goodin, R.E. (1996) The Theory of Institutional Design, Cambridge University Press, Cambridge.

Helmke, G. and Levitsky, S. (2004) Informal institutions and comparative politics: A research agenda. Perspectives on Politics, 2(04), 725-40.

lacuone, D. (2005) "Real men are tough guys": Hegemonic masculinity and safety in the construction industry. The Journal of Men's Studies, 13(2), 247-66.

Isaacs, E. (2013) The value of rapid ethnography, in Jordan, B. (ed.) Advancing ethnography in corporate environments: challenges and emerging opportunities, Left Coast Press, Walnut Creek, CA, 92-107.

John, P. (2013) Analyzing public policy, Routledge, Abingdon, Oxon, New York.

Krook, M.L. and Mackay, F. (2011) Gender, Politics, and Institutions: Towards a Feminist Institutionalism, Palgrave Macmillan, Basingstoke.

Lauth, H.J. (2000) Informal institutions and democracy. Democratization, 7, 21-50.

Lewis, S. and Humbert, A.L. (2010) Discourse or reality? "Work-life balance", flexible working policies and the gendered organization. Equality, Diversity and Inclusion: An International Journal, 29(3), 239-54.

Lowndes, V. (1996) Varieties of new institutionalism: A critical appraisal. Public Administration, 74(2), 181-97.

Lowndes, V. (2002) Institutionalism. In Marsh, D. \& Stoker, G. (eds.) Theories and Methods in Political Science, London, Palgrave, 90-108.

Lowndes, V. and Roberts, M. (2013) Why Institutions Matter: The New Institutionalism in Political Science, Palgrave Macmillan, Basingstoke.

Lowndes, V. and Wilson, D. (2003) Balancing revisability and robustness? A new institutionalist perspective on local government modernization. Public Administration, 81, 275-98.

Mackay, F., Kenny, M. and Chappell, L. (2010) New institutionalism through a gender lens: Towards a feminist institutionalism? International Political Science Review, 31 (5), 578-88.

Mahoney, J. and Thelen, K. (2010) Explaining Institutional Change: Ambiguity, Agency, and Power, Cambridge University Press, Cambridge. 
March, J.G. and Olsen, J.P. (1984) The new institutionalism: Organizational factors in political life, The American political science review, 734-49.

Massey, D.B. (1994) Space, Place, and Gender, University of Minnesota Press, Minneapolis.

Meisel, Z.F. and Karlawish, J. (2011) Narrative vs evidencebased medicine-and, not or. Journal of the American Medical Association, 306(18), 2022-3.

Meyer, J.W. and Rowan, B. (1991) Institutionalised organisations: Formal structure as myth and ceremony, in Dimaggio, P.J. and Powell, W.W. (eds.) The New Institutionalism in Organizational Analysis, University of Chicago Press, Chicago, IL, 63-83.

Millen, D.R. (2000) Rapid ethnography: time deepening strategies for $\mathrm{HCl}$ field research, AT\&T LabsResearch: New York.

Murray, R. (2014) Quotas for men: Reframing gender quotas as a means of improving representation for all. American Political Science Review, 108(03), 520-32.

Newman, J. (2001) Modernising Governance: New Labour, Policy and Society, Sage, London.

Patton, E. and Appelbaum, S.H. (2003) The case for case studies in management research. Management Research News, 26, 60-71.

Powell, A. and Sang, K.J.C. (2013) Equality, diversity and inclusion in the construction industry. Construction Management and Economics, 31(8), 795-801.

Raymond, L., Weldon, S.L., Kelly, D., Arriaga, X.B. \& Clark, A.M. (2013) Making change: Norm-based strategies for institutional change to address intractable problems. Political Research Quarterly, 1065912913510786.

Sang, K.J.C. and Powell, A. (2012) Equality, diversity, inclusion and work-life balance in construction, in Dainty, A. and Loosemore, M. (eds.) Human Resource Management in Construction: Critical Perspectives, Routledge, Abingdon, pp. 163-96.

Toohey, T., Colosimo, D. and Boak, A. (2009) Australia's Hidden Resource: The Economic Case for Increasing Female Participation, Goldman Sachs JBWere, Sydney.

Watts, J. (2007) Porn, pride and pessimism: Experiences of women working in professional construction roles. Work, Employment and Society, 21(2), 219-316.

Workplace Gender Equality Agency (2012) Industry Snapshot: Construction, Australian Government, Sydney. 
Table 1: Document descriptions

\begin{tabular}{|c|c|c|c|}
\hline \multirow[t]{2}{*}{ Policy themes } & \multirow[t]{2}{*}{ Policy description } & \multicolumn{2}{|c|}{$\begin{array}{l}\text { Number of policies } \\
\text { analysed }\end{array}$} \\
\hline & & Company A & Company B \\
\hline Flexibility & $\begin{array}{l}\text { Guidelines, expectations and reasoning of flexible } \\
\text { work opportunities for employee } \\
\text { and managers }\end{array}$ & 2 & 2 \\
\hline Diversity & $\begin{array}{l}\text { Aims, objectives, strategy and responsibilities. } \\
\text { Internal research including: focus groups, } \\
\text { employee survey results. Employee gender } \\
\text { transitioning procedure }\end{array}$ & 6 & 5 \\
\hline People & $\begin{array}{l}\text { HR employee development strategy and company } \\
\text { employee inductions }\end{array}$ & 3 & - \\
\hline Recruitment & $\begin{array}{l}\text { Internal and external recruitment processes, } \\
\text { assessment and selection principles and tools } \\
\text { including legislative requirements }\end{array}$ & - & 1 \\
\hline $\begin{array}{l}\text { Learning and } \\
\text { development }\end{array}$ & $\begin{array}{l}\text { Company and employee commitment to employee } \\
\text { development. Graduate, leadership, manager } \\
\text { learning modules. Outline of company values and } \\
\text { core principles }\end{array}$ & 21 & 2 \\
\hline Code of conduct & $\begin{array}{l}\text { Company ethics, acceptable conduct and } \\
\text { consequences of non-conformance }\end{array}$ & 1 & 1 \\
\hline $\begin{array}{l}\text { Parental and } \\
\text { care leave }\end{array}$ & $\begin{array}{l}\text { Parental, care, emergency leave entitlements and } \\
\text { conditions }\end{array}$ & 1 & 5 \\
\hline Performance & $\begin{array}{l}\text { Employee performance process: timing, evaluation } \\
\text { criteria, employee development } \\
\text { plan }\end{array}$ & 6 & 1 \\
\hline Remuneration & $\begin{array}{l}\text { Strategy, employee incentive plan and manager } \\
\text { information. Gender pay gap } \\
\text { research }\end{array}$ & 5 & - \\
\hline $\begin{array}{l}\text { Talent and } \\
\text { succession }\end{array}$ & $\begin{array}{l}\text { Aims, manager guidelines including bias in } \\
\text { decision-making and scenario planning }\end{array}$ & 3 & 2 \\
\hline $\begin{array}{l}\text { Harassment and } \\
\text { bullying }\end{array}$ & Legislative responsibilities & - & 2 \\
\hline
\end{tabular}

Table 2: Sample description (n)

\begin{tabular}{lccc}
\hline & Total & Company A & Company B \\
\hline Total interviews & 20 & 10 & 10 \\
Men & 12 & 6 & 6 \\
Women & 8 & 4 & 4 \\
Senior executives (incl CEO, COO) & 16 & $8 *$ & 8 \\
$\begin{array}{l}\text { Diversity leaders (incl diversity manager, HR manager, } \\
\text { policy authors) }\end{array}$ & 5 & 3 & 2 \\
Functional roles & & & 4 \\
Operational roles & 10 & 6 & 6 \\
\hline
\end{tabular}

Notes: *numbers may not add, as interviewees held multiple roles 
Table 3: Summary of robustness and revisability of company policies

\begin{tabular}{|c|c|c|c|c|c|c|c|c|}
\hline \multirow{3}{*}{$\begin{array}{l}\text { Policy themes } \\
\\
\text { Company }\end{array}$} & \multicolumn{4}{|c|}{ Robustness } & \multicolumn{4}{|c|}{ Revisability } \\
\hline & \multicolumn{2}{|c|}{ Values } & \multicolumn{2}{|c|}{ Enforcement } & \multicolumn{2}{|c|}{ Flexibility } & \multicolumn{2}{|c|}{ Variability } \\
\hline & A & B & A & $\mathrm{B}$ & A & $\mathrm{B}$ & A & $\mathrm{B}$ \\
\hline Flexibility & $\mathrm{O}$ & $\mathrm{O}$ & 0 & $x$ & 0 & $x$ & $\mathrm{O}$ & $\mathrm{O}$ \\
\hline Diversity & $\mathrm{X}$ & 0 & $x$ & 0 & 0 & $\mathrm{O}$ & 0 & 0 \\
\hline People & $\mathrm{O}$ & - & $\mathrm{X}$ & - & 0 & - & $x$ & - \\
\hline Recruitment & - & $x$ & - & $x$ & - & $x$ & - & $\mathrm{x}$ \\
\hline Learning and development & 0 & $\mathrm{X}$ & $\mathrm{X}$ & $\mathrm{X}$ & $x$ & $\mathrm{x}$ & 0 & $\mathrm{X}$ \\
\hline Code of conduct & $\mathrm{O}$ & 0 & 0 & $\mathrm{O}$ & $x$ & $x$ & $x$ & 0 \\
\hline Parental and care leave & $x$ & $x$ & $x$ & $\mathrm{O}$ & 0 & $x$ & $x$ & 0 \\
\hline Performance & 0 & 0 & $x$ & - & 0 & $x$ & - & $\mathrm{O}$ \\
\hline Remuneration & $x$ & - & 0 & - & 0 & - & 0 & - \\
\hline Talent and succession & $\mathrm{X}$ & $x$ & $x$ & $x$ & $x$ & $x$ & 0 & 0 \\
\hline Harassment and bullying & - & 0 & - & $\mathrm{O}$ & - & $\mathrm{O}$ & - & $\mathrm{O}$ \\
\hline
\end{tabular}

